\title{
Sport sponsorship from perspective of great industrial companies' managers
}

\author{
Iman MIRZAEI ${ }^{1}$, Abdolrahman MEHDIPOUR ${ }^{2}$, Tahereh AZMSHA ${ }^{2}$ \\ ${ }^{1}$ Shahid Chamran University of Ahwaz, Iran. \\ 2 Faculty of Sport Management, University of Shahid Chamran, Ahwaz, Iran \\ Address Correspondence to I. Mirzaei, e-mail: imanmm91@gmail.com
}

\begin{abstract}
The objective of this research was to analysis the perspective of great industrial companies' managers about effective factors on attracting sponsors in professional sport. According to this objective, the statistical population of this study included senior managers of all great industrial companies in Khuzestan province in Iran. The questionnaire of this study was a scholar-made questionnaire which its Content validity was confirmed by professors and sport management experts and its reliability and construct validity were also examined. In order to analyze the data of this research, exploratory factor analysis and path analysis methods were used by SPSS and Smart-PLS software. Exploratory factor analysis demonstrated that there are 4 factors attracting sponsors and these factors indicated $68 / 8 \%$ of total variance. These factors were "economic-marketing", "media", "legal and juridical" and finally "sport teams and spectators". According to the final results of path analysis, media factor gained the first rank among 4 recommended total factors. Based on the findings of the present research, it is suggested that officials and managers of sport teams in order to attract sponsors from industrial companies, should have special attention to cases such as improve the quality and use of modern technology in live broadcasting of sport events, spreading media coverage of sport events, creating and using laws related to TV broadcasting rights, Employing famous players and coaches in sport teams and attracting more spectators.
\end{abstract}

Keywords: Company managers, Smart-PLS, sport sponsorship.

\section{INTRODUCTION}

The vast majority of major sporting events are sponsored in some way. In the past 40years, sponsorship has evolved from the traditional, shortterm corporate donations that were designed to boost management egos into long-term, economic-based relationships between sponsor and sponsored properties and that are typically grounded by complex legal agreements (10). Event sponsorship is a common marketing tool today(16). The sponsorship involves an exchange between a sponsor and the event property; the property sells the right to associate with the event to the sponsor, thereby providing leverage opportunity to the sponsor to exploit its communications to consumers (14). Event sponsorship has been recognized as an effective means through which companies can communicate with target markets and attendees of sports events (4).
Revenue from sporting events and sponsorship has become increasingly important to marketing practitioners within the sports industry(4). In recent years, sponsorship has morphed from a passive form of marketing that was often philanthropic in nature, to a key strategic business building initiative that as a legitimate element of the promotional mix. The International Events Group, IEG (2013) projects that in 2013, global spending on sponsorship reached US \$ 53.3 billion (a75\% increase since 2005) and sponsorship spending by North American companies increased by $5.5 \%$, while media spending rose by only $2.6 \%$ and promotional spending remained flat (12). Linking the brand with an event via sponsorship enables companies to reach consumers' interest and attention by associating with the events that hold great importance to them. Sponsorship bypasses media clutter and provides an environment where a brand can reach and communicate with the right 
target audience and differentiate itself from the other brands (1). Consumers mostly regard advertising as a self-interested marketing activity and believe that the advertising company of brand cannot increase its interest in the company and brand (14). Therefore, sport sponsorship has many advantages as an element of sport marketing mix and it is more effective than regular advertising (15). So, companies are allocating significant amounts of money to sponsorship. Although sponsorship activities have been popular and ubiquitous in most developed countries, sponsorship for Iranian companies and sports clubs is still a new phenomenon.

Investigating the effective factors on attracting sponsors is not the subject of any research in Iran and there is no comprehensive consensus on the selection of effective factors on attracting sponsors, so this issue needs further studies. Aside from the lack of a general consensus in the field of attracting sponsors in Iran, research on the perspective of great industrial companies' managers about effective factors on attracting sponsors has not done. Research gap in this issue is well perceived. Also, despite large active industrial companies operating in Iran and especially in Khuzestan province, the sport sponsorship in this region is so weak and professional sport of this region is in trouble. So, the present study was done to analyze and prioritize the factors attracting sponsors from managers of great industrial companies' point of view in the professional sports and seeks to answer the following questions: 1) What are the factors attracting sponsors in the professional sports from the perspective of managers of great industrial companies? 2) What are the priorities of these factors? 3) How is the status of sport sponsorship done by great industrial companies?

\section{MATERIAL \& METHOD}

The population of present study included senior managers of all great industrial companies (including managing director, financial director or sales manager) in Khuzestan province in Iran. Based on the statistics of Industry, Mine and Trade organization in Khuzestan province, there are 207 great active industrial companies which among them 178 companies are privately owned and the rest are public. In private industrial companies and according to Morgan table, the number of 123 companies was selected as sample of the research. In the public companies including 29 great industrial companies, statistical sample considered as statistical population. Finally, a total of 125 questionnaires were collected. Data collection instrument was scholar-made questionnaire which its Content validity was confirmed by professors and sport management experts. Its construct validity were examined through Kaiser-Meyer-Olkin's test $(\mathrm{KMO}=0 / 94)$ and its reliability were examined through Cronbach's alpha $(\alpha=0 / 97)$. In order to analyze the present data, exploratory factor and path analysis methods were used by SPSS and Smart-PLS software.

\section{RESULTS}

To determine the adequacy of sampling in factor analysis, Kaiser-Meyer-Olkin's test was used. The results of this test have been illustrated in table 1 .

Table 1. Kaiser-Meyer-Olkin's and Bartlett's Test

\begin{tabular}{lc} 
KMO & 0.948 \\
\hline Approx. Chi-square & 12943.610 \\
df & 630 \\
Sig. & 0.000 \\
\hline
\end{tabular}

As results of table 1 showed, index of KaiserMeyer-Olkin's test is equal with 0/913 and as respects whatever amount of this index close to one, it illustrates that sampling is proper and we can deduce that data are suitable for factor analysis. In order to understand the correlation between the studied items Bartlett's test was used. The results of this test have been shown in Table 1. Significant level of the test results indicates that data can form factors.

Table 2. Frequency distribution by type of sample.

\begin{tabular}{lcc}
\hline Type of sample & Frequency & Frequency Distribution Percentage \\
\hline Managers of public industrial companies & 22 & 17.6 \\
Managers of private industrial companies & 103 & 82.4 \\
\hline
\end{tabular}


Table 3. Frequency distribution of industrial companies based on performing sport sponsorship.

\begin{tabular}{lcccc}
\hline Type of ownership & $\begin{array}{c}\text { Performing sport } \\
\text { sponsorship }\end{array}$ & Frequency & $\begin{array}{c}\text { Frequency distribution } \\
\text { percentage }\end{array}$ & $\begin{array}{c}\text { The cumulative frequency } \\
\text { percentage }\end{array}$ \\
\hline Public Companies & Yes & 9 & $\% 40.9$ & $\% 40.9$ \\
& No & 13 & $\% 59.1$ & $\% 100$ \\
Private Companies & Total & 22 & $\% 100$ & $\% 6.8$ \\
& Yes & 7 & $\% 6.8$ & $\% 100$ \\
& No & 96 & $\% 93.2$ & $\% 100$ \\
\hline
\end{tabular}

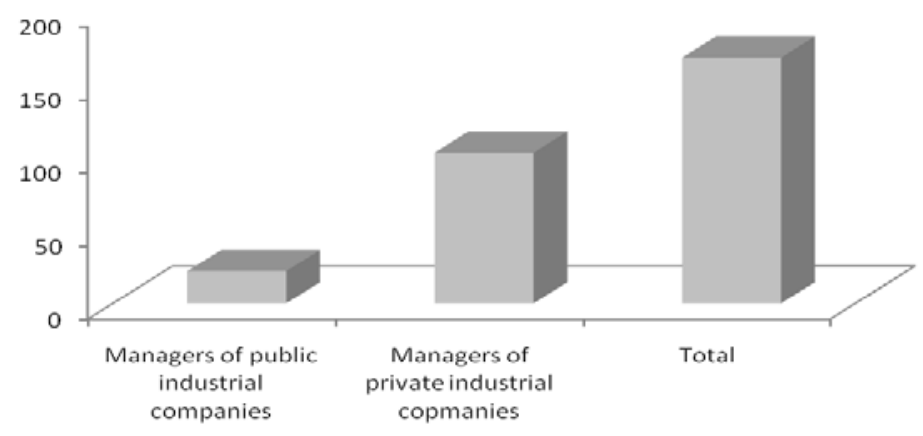

Figure 1. Frequency distribution based on the sample.

Table 4. Summary of variables in each factor according to the highest and lowest correlation.

\begin{tabular}{llc}
\hline Factors & \multicolumn{1}{c}{ Items } & Correlations \\
\cline { 2 - 3 } Economic-Marketing & Creating sports marketing professional agencies & 0.83 \\
\multirow{2}{*}{ Sport teams and Spectators } & Paying low interest credit by banks to companies sponsor sports & 0.59 \\
& Sport teams place in league tables & 0.84 \\
Media & Employing famous players and coaches in sport teams & 0.58 \\
& Create private television networks & 0.80 \\
Legal - Juridical & Improving media coverage of sport events & 0.61 \\
& Creating and using laws related to TV broadcasting rights & 0.56 \\
\hline
\end{tabular}

According to table 3, in the last year, 40.9 percent of the Public industrial companies have sponsored sports and 59.2 percent of them have not sponsored sports. Also, 6.8percent of the private industrial companies have sponsored sports and 93.2 percent of them have not sponsored any of the areas of sport. In order to identify effective factors in attracting sponsors and categorize of these factors, statistical method of exploratory factor analysis was used. Results of Exploratory factor analysis demonstrated that there are 4 factors attracting sponsors and these factors indicated $68 / 8 \%$ of total variance. According to the title of threads; factors named as following: economic and marketing factor, sport teams and spectators factor, media factor and ultimately legal and juridical factor. After identifying factors in the next step, components of each factor were determined.

\section{Fitting the measurement model}

\section{Investigation of reliability, convergent and divergent validity}

Convergent validity investigates the amount of correlation of each structure with questions (indexes).

According to table 5 any of research variables have obtained the combined reliability CR $>0.7$ (11) average variance extracted AVE $>0.5$ (6) and Cronbach's alpha value above 0.70 percent (5). In conclusion acceptable condition of reliability and convergent validity of present research confirmed. Items 2, 12, 21, 41, 45, and 46 were excluded because of the lower degree of reliability.

Table 6 has derived from the Fornell \& Larker method (6), by considering the square root of the 
average variance extracted (AVE). Hidden variables of the model can be seen in the main diagonal of the table which is greater than the value of their correlation with each other. So, the appropriate divergent validity and good fitting of the measurement model are confirmed.

\section{Fitting of the structural and total model}

According to results of the path analysis of relationships between variables, positive, direct and significant affect on factors confirmed on attracting sponsors. Economic - marketing factor $(\beta=0.33, t>1.96)$, sport teams and spectators factor $(\beta=0.24, \mathrm{t}>1.96)$, legal and Juridical factor $(\beta=0.36, t>1.96)$ and media factor $(\beta=0.42, \mathrm{t}>1.96)$. This indicate that sport teams and spectators factor $(0.24 \%)$, economic-marketing factor $(0.33 \%)$, legal - Juridical factor $(0.36 \%)$, and media factor $(0.42 \%)$ explain the variance and attracting changes of the attracting sponsors. Thus in confidence level of $0.95 \%$, the assumption of the relation between economic-marketing factor, sport teams and spectators factor, media factor and legal and Juridical factor on attracting sponsors were confirmed. But the greatest impact on attracting sponsors was related to media factor (0.42), legal - juridical factor (0.36), economicmarketing factor $(0.33)$ and ultimately Sports teams and spectators factor $(0.24)$.

Table 5. Summary of Factor loads value (maximum and minimum factor load) for each group and results of convergent validity and reliability of research variables.

\begin{tabular}{|c|c|c|c|c|c|}
\hline Factors & Items & Loadings & $\mathrm{CA}^{3}$ & $\mathrm{CR}^{2}$ & $\mathrm{AVE}^{1}$ \\
\hline \multirow[t]{2}{*}{ Media } & Improve the quality and use of modern technology in live broadcasting of sport events & 0.88 & 0.91 & 0.93 & 0.70 \\
\hline & Improving media coverage of sport events & 0.79 & & & \\
\hline Legal - Juridical & $\begin{array}{l}\text { Creating and using laws related to TV broadcasting rights } \\
\text { Having authority in ticket sales by sport clubs }\end{array}$ & $\begin{array}{l}0.92 \\
0.88\end{array}$ & 0.88 & 0.93 & 0.81 \\
\hline Sport teams and & Employing famous players and coaches in sport teams & 0.86 & 0.87 & 0.90 & 0.58 \\
\hline Spectators & Creating Fan Clubs by sport teams & 0.55 & & & \\
\hline \multirow[t]{2}{*}{ Economic-Marketing } & Creating sports marketing professional agencies & 0.84 & 0.95 & 0.96 & 0.61 \\
\hline & Paying low interest credit by banks to companies sponsor sports & 0.68 & & & \\
\hline \multirow[t]{2}{*}{ Attracting Sponsors } & $\begin{array}{l}\text { In your opinion how much industrial companies' sponsorship from professional sport } \\
\text { has grown? }\end{array}$ & 0.90 & 0.74 & 0.88 & 0.79 \\
\hline & How well do you know the level of sport sponsorship in this region? & 0.87 & & & \\
\hline
\end{tabular}

${ }^{1}$ Average Variance Extracted; ${ }^{2}$ Composite Reliability; ${ }^{3}$ Cronbachs' Alpha

Table 6. Divergent validity results of the research variables measurement model are confirmed.

\begin{tabular}{llllll}
\hline \multicolumn{1}{c}{ Research variables } & 1 & 2 & 3 & 4 \\
\hline 1 & Attracting Sponsors & 0.89 & & & \\
2 & Economic-Marketing & 0.60 & 0.78 & & \\
3 & Sport teams and Spectators & 0.54 & 0.45 & 0.76 & 0.83 \\
4 & Media & 0.75 & 0.69 & 0.69 & 0.69 \\
5 & Legal - Juridical & 0.53 & 0.59 & 0.68 & 0.90 \\
\hline
\end{tabular}

Table 7. Results of path analysis related to variables of research.

\begin{tabular}{|c|c|c|c|c|c|c|}
\hline Criterion variable & Predictor variables & $(\beta)$ & (T-values) & hypothesis terms & $\mathrm{R}^{2}$ & $1-\mathrm{R}^{2}$ \\
\hline \multirow[t]{4}{*}{ Attracting Sponsors } & Media & $0 / 42$ & 5.11 & Supported & & \\
\hline & Legal - Juridical & $0 / 36$ & 2.68 & Supported & 0.58 & 0.42 \\
\hline & Economic-Marketing & $0 / 33$ & 2.28 & Supported & & \\
\hline & Sport teams and Spectators & $0 / 24$ & 2.03 & Supported & & \\
\hline
\end{tabular}

Table 8. Fitting of research structural model.

\begin{tabular}{lcc}
\hline Endogenous variable & $\mathrm{R}^{2}$ & GOF (Goodness of Fit) \\
Attracting Sponsors & 0.58 & 0.63 \\
\hline
\end{tabular}




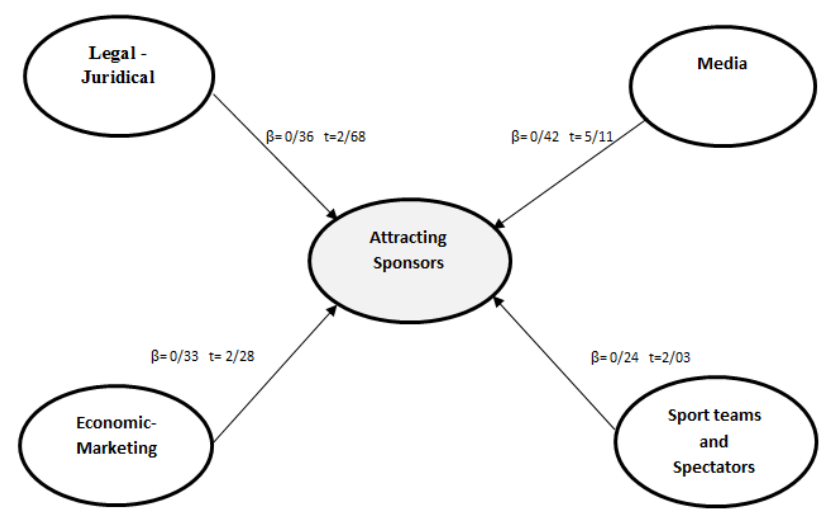

Figure 2. Has illustrated statistical model of the research.

$\mathrm{R}^{2}$ value is calculated only for dependent structures of the model and for exogenous constructs value, this criterion is zero(8). $R^{2}=0 / 58$ demonstrate the suitability of the relation between the exogenous structures and endogenous constructs. GOF is computational criterion which is square root of average of AVE multiplied by $\mathrm{R}^{2}$ that confirm total fitting of path analysis of structural model. Wetzels et al. (17) introduced three values of $0.01,0.25$, and 0.36 respectively as weak, medium, and strong. Fitting of total part can be controlled by this criterion. According to the results reported in table 8 good fitting of the overall model is confirmed.

\section{DISCUSSION}

Results of present research revealed that 4 factors are effective in attracting sponsors in Khuzestan province included "media", "legal - juridical", "economic - marketing", and "sport teams and spectators". By using path analysis, priority of each factor was determined. The first and main factor for attracting sponsors was media and other factors respectively include legal - juridical, economic marketing and sport teams and spectators.

The first factor, namely media determined as the most important factor in attracting sponsors, which include "Improve the quality and use of modern technology in live broadcasting of sport events" as the most important item and "support of press from sport sponsors", "Increase the number of live TV broadcast of sport events on the various TV networks", "Create private television networks", "Investing in creating websites for e-commerce by sport clubs" and "Improving media coverage of sport events" as the less important item. One of the main aims of companies which are involved in sponsorship activities is achieving media coverage. Media coverage of sport events is very important for sponsors. Because their financial support are for introducing their products and brand. So by broad media coverage these companies can reach to large market which this issue has very importance.

Heerden (7) did a research in South Africa with the aim of investigation of effective factors in decision of sponsors involving in sponsorship activities, their results illustrated that media programs by sponsored team or organization was the most important factor in attracting sport sponsors which is consistent with the results of the present study. Also, results of present study are consistent with results of Berrett \& Slack (2), Ivarsson (9), Seguin \& O'Reilly (13) which illustrated the role of media coverage and global advertising are important in attracting sport sponsors and also they explained whatever TV and satellite broadcast of sport events at national and international level be broader, amount of attracting sponsors will increase.

Factor number 2, namely Legal - Juridical factor includes these items: "Creating and using laws related to TV broadcasting rights" as the most important item and "law enforcement of privatization of state industrial companies, thereby creating a competitive structure in the economy", "law enforcement of copyright" and "Having authority in ticket sales by 
sport clubs" as less important item. In Iran according to Article 44 of the constitution, all sport clubs must be private and financially efficient but so far these rules have not been fully implemented. Also, lack of copyright laws which paved the way to financial support causes sponsors to bereluctantto invest. Undoubtedly, Legislation and incentives for sponsors will increase their interest to invest and it will give them more confidence to achieve their goals. Results of present study in this part are consistent with results of Heerden (7) and Ying (18) which illustrated lack of law about the sponsors of professional sports is most important weakness in sport field of some countries.

Factor number 3, namely economic-marketing factor includes items of "Creating sports marketing professional agencies" as the most important item and "utilization of sport marketing experts", "Observing Communicational and motivational principles with potential sponsors by sport teams marketers", "utilization of the Advanced equipment and facilities of advertising", "Developing strategic and operational plans for sports marketing", "Transparency of economic and financial information of sports clubs", giving Awareness to industrial companies about the benefits of sport sponsorship" and "Paying low interest credit by banks to companies sponsor sports" mentioned as the less important item. With all the importance of the sport marketing, for various reasons it has not been considered particularly in Iran and still real implications of sport marketing in our society is unknown. Lack of sport marketing experts in our sport federations and sport clubs caused their officials not be able to attract any sponsors.

Factor number 4, namely sport teams and spectators includes "employing famous players and coaches in sport teams" as the most important item and "Sport teams place in league tables", "the number of spectators at sport events", "The popularity of sports teams", "Spectators commitment to consume goods and services of the sponsors" and "Creating Fan Clubs by sport teams" as the less important item. Lack of significant interest from sports fans even at the level of national championships in the country is considerable issue. In our country big turnout of spectators even in popular sports such as soccer competition is limited to special events that this issue caused lack of interest in industrial companies to sponsor sport teams. Undoubtedly presence of famous coaches and players in sport teams cause media attention and as a result attracting sponsors. The results of this paper are consistent with results of Seguin and O'Reilly (13)which illustrated that present of famous athletes in sport teams is one of the reasons of private companies' investment. Also Berument (3) implied that recruit famous players simultaneously causes successful of clubs, improve the clubs prestige, attracting more financial resources and ultimately will enhance the club's stock price which is consistent with the results of present research.

Finally, Based on the findings of the present research, it is suggested that officials and managers of sport teams in order to attract sponsors from industrial companies, should have special attention to cases such as improve the quality and use of modern technology in live broadcasting of sport events, spreading media coverage of sport events, creating and using laws related to TV broadcasting rights, Employing famous players and coaches in sport teams and attracting more spectators. In this study, we only examine the Factors Attracting Sponsors from perspective of great industrial companies' managers. In future studies, we can investigate factors attracting sponsors from service organizations. Also we can investigate factors attracting sport sponsorship from fans' perspective. Another fruitful area of future empirical research might focus on examining the effects of popular sports on attracting sponsors.

\section{ACKNOWLEDGEMENTS}

The authors would like to sincerely thank the constructive remarks and suggestions given by Sport management Professors Especially in relation to the construction of the questionnaire and we greatly appreciated the cooperation of officials of Industry, Mine and Trade organization in Khuzestan province.

\section{REFERENCES}

1. Areska J. The impact of Sport Sponsorship on Brand Equity: The Analysis of Red Bull GmbH. Bachelor Thesis FOR Degree in Marketing and Management Communication. Aarhus University; 2012.

2. Berrett T, Slack T. A framework for the analysis of strategic approaches employed by non-profit sport organizations in seeking corporate sponsorship. Sport Management Review, 2001; (4): 21-45.

3. Berument H. Performance of soccer on the stock market; Evidence from Turkey. Social Sciences, 2006; 43(4): 695-699. 
4. Choi J. An investigation of sponsorship implications within a state sports festival: the case of the Florida Sunshine State Games. International Journal of Sports Marketing \& Sponsorship, 2011; January.

5. CronbachL J. Coefficient alpha and the internal structure of tests. Psychometrika, 1951; 16(3):297-334.

6. Fornell C, Larker DF. Evaluating structural equation models with unobservable variables and measurement error. Journal of marketing research, 1981; 12: 39-50.

7. Heerden V. Factors affecting decision-making in South African sport sponsorships. Doctoral Thesis in Marketing and Communication Management. University of Pretoria. 2001.

8. Henseler J, Ringle C, Sinkovics R. The use of partial least squares path modeling in international marketing. Advances in International Marketing, 2009; 20: 277-320.

9. Ivarsson C, Johnson M. Sport Sponsorship as a promotional tool. Bachelors Thesis, Industrial Marketing and e- Commerce. Lulea University of Technology. 2004.

10. Mazodier M, Quester P. The role of sponsorship fit for changing brand affect: A latent growth modeling approach. International Journal of Research in Marketing, 2014; 31(1): 16-29.

11. Nunnally J. Psychometric theory. 2nded.New York, McGrawHill, 1978.
12. O'Reilly N, Horning L. Leveraging Sponsorship: The activation ratio. Sport Management Review, 2013; (16): 424-437.

13. Seguin B, Teed K, O'Reilly N. National sports organizations and sponsorship: an identification of best practices. International Journal of Sport Management and Marketing, 2005; 1(1/2): 69-92.

14. Simmons C, Becker-Olsen K. Achieving marketing objectives through social sponsorships. Journal of Marketing, 2006; 70(4): 154-169.

15. Smith A. Introduction to sport marketing. Sport management series, 2008; (8): 326.

16. Uhrich S, Koeinigstrofer J, Groeppel-Kelin A. Leveraging sponsorship with corporate social responsibility. Journal of Business Research, 2013; Article in Press.

17. Wetzels M, Odekerken-Schroder G, Van Oppen C. Using PLS path modeling for assessing hierarchical construct models: Guidelines and empirical illustration. MIS Quarterly, 2009; 33(1): 177.

18. Ying F. Event Sponsorship in China, Corporate Communications. An International Journal, 2002; 7 (2): 110-116. 